\title{
Avoiding Occupational Diseases in Industry by Adapting the Training Methods to the New Technologies
}

\author{
Petru Iulian MURESAN \\ Transilvania University of Brasov, Romania, petru.muresan@unitbv.ro \\ Ioan MILOSAN \\ Transilvania University of Brasov, Romania, milosan@unitbv.ro \\ Dorin SENCHETRU \\ Territorial Labor Inspectorate of Brasov, Romania, dorin senchetru@yahoo.com \\ Adrian Nicolae REIT \\ Territorial Labor Inspectorate of Brasov, Romania, adrianreit@yahoo.com
}

\begin{abstract}
The most common occupational diseases in the industry are mainly due to the non-compliance with the employer's obligation to provide appropriate training in the workplace. This is often performed only by signing training forms only formally. With this fact in mind, we analyze in this paper the occupational diseases in industry specific to Brașov County, presented in the reports of Brașov Labor Inspectorate, from 2005 to 2019. This study was conducted based on the number of occupational diseases due to silicosis, related to the total number of occupational diseases in Brașov County (study period between 2005 and 2019). Given the state of emergency generated by the COVID-19 pandemic, in order to prevent the spread of this virus and to carry out activities using work from home, telework, and to avoid the interaction between workers as much as possible, online communication with employees is considered as being the only way that allows at the same time both the observance of the measures imposed to prevent the spread of the virus and the implementation of the obligations regarding training on occupational safety and health, which the employer has according to the laws in force. In this context, analyzing the values obtained from the experimental data (number of occupational diseases due to silicosis, related to the total number of occupational diseases in Brasov County) it is identified and solved in the paper the use of online environment, especially in remotely training the workers, who have the opportunity to receive training documents, analyze them, sign them electronically and send them to the employer in electronic format and in this way, being trained even in special situations.
\end{abstract}

\section{Keywords}

OHS, occupational diseases, silicosis, online training

\section{Introduction}

It can say with certainty that silicosis is a chronic, incurable lung disease, which is the result of the entry and accumulation in the lungs of powders containing free crystalline silicon dioxide $\left(\mathrm{SiO}_{2}\right)$ and the reaction of the lungs to the presence of these powders [1-5]. This occupational disease is ranked first and it is the most common collagen pneumoconiosis, in the world morbidity due to occupational diseases.

Complications of silicosis are represented by: respiratory infectious complications, chronic bronchitis, pulmonary emphysema, pneumothorax, respiratory failure, chronic pulmonary heart [6-11].

Bearing in mind that occupational diseases due to workers' exposure to silicosis dust have a quick evolution (the evolution of the disease can be 1-5 years) must be considered and pay close attention to workers working in these conditions.

Legislative measures and obligations must be implemented at the level of each specific unit so as to minimize this risk of occupational disease as much as possible and to place special emphasis on training exposed staff, taking into account the fact that many workers are not aware of the danger.

An important role is also played by the labor medicine doctor, who must periodically examine (according to legal medical regulations) the exposed workers [12-14]. They are able to set the initial 
diagnosis of suspected disease. In case of confirmation, the worker must change their activity or, as the case may be, the third degree retirement for illness with the right to work or the effective retirement for the illness [15-17].

Unfortunately, it does not exist a curative treatment for this disease, but complications can be treated for example with antibiotics against seasonal respiratory infections, etc.).

Through this article it is intended to attract attention to the need to train workers on how to perform tasks and how to protect.

\section{Case Study: Occupational Diseases Due to Silicosis, in Brașov County}

In the case study, the number of occupational diseases due to silicosis was taken into account, related to the total number of occupational diseases in Brașov County (the study period between 2005 and 2019) [18].

Occupational silicosis was chosen in the case study because it is found with a significant number of diseases each year of the analyzed period (unlike other diseases such as hearing loss, pulmonary fibrosis, thoracic-filling vertebral discopathy, tendonitis and tenosynovitis of the tendons, pneumoconiosis, asbestosis, asthma, occupational diseases which are not found every year).

The total number of occupational diseases in Brasov County between 2005 and 2019 (highlighting the number of occupational diseases due to silicosis) are presented in Table 1.

Table 1. Occupational diseases in Brașov County between 2005 and 2019 [18]

\begin{tabular}{|c|c|c|c|}
\hline Year & $\begin{array}{c}\text { Total number of detected } \\
\text { occupational diseases (IPT) }\end{array}$ & $\begin{array}{c}\text { Total number of diseases } \\
\text { due to silicosis (IPSil) }\end{array}$ & $\begin{array}{c}\text { IpSil/IPT } \\
{[\%]}\end{array}$ \\
\hline 2005 & 31 & 8 & 25.81 \\
\hline 2006 & 53 & 15 & 28.30 \\
\hline 2007 & 143 & 9 & 6.29 \\
\hline 2008 & 124 & 27 & 21.77 \\
\hline 2009 & 36 & 13 & 36.11 \\
\hline 2010 & 26 & 6 & 23.08 \\
\hline 2011 & 24 & 13 & 54.17 \\
\hline 2012 & 8 & 3 & 37.50 \\
\hline 2013 & 12 & 5 & 41.67 \\
\hline 2014 & 6 & 6 & 100.00 \\
\hline 2015 & 8 & 1 & 12.50 \\
\hline 2016 & 13 & 6 & 46.15 \\
\hline 2017 & 5 & 4 & 80.00 \\
\hline 2018 & 2 & 1 & 50.00 \\
\hline 2019 & 2 & 2 & 100.00 \\
\hline Total & 493 & 119 & - \\
\hline
\end{tabular}

Figure 1 shows the variation of the IPSil / IPT ratio in Brașov County during 2005-2019.

Analyzing the data presented in Table 1 and Figure 1, it is noted that the maximum value specific to the IpSil / IPT ratio is obtained in 2014 and 2019, years in which silicosis was the only type of occupational disease in Brasov County.

\section{Methods to Avoid Occupational Diseases}

Certainly occupational disease or a risk of injury cannot be eliminated or minimized if it is not identified and assessed. Therefore, it is necessary for a job to be assessed periodically for the risks of occupational injury and illness.

In most cases, the occupational disease risk cannot be completely eliminated, which is why it must be kept within acceptable limits.

What can be done? 
- providing the technical equipment with all the necessary protection devices;

- delivering all the specifications regarding the modalities of operation, maintenance and repairs, as well as security together with the equipment;

- training the worker with the acquisition and observance of his / her own occupational health and safety instructions and of the norms, norms and internal regulations of occupational safety, as well as on the procedures and measures for their application.

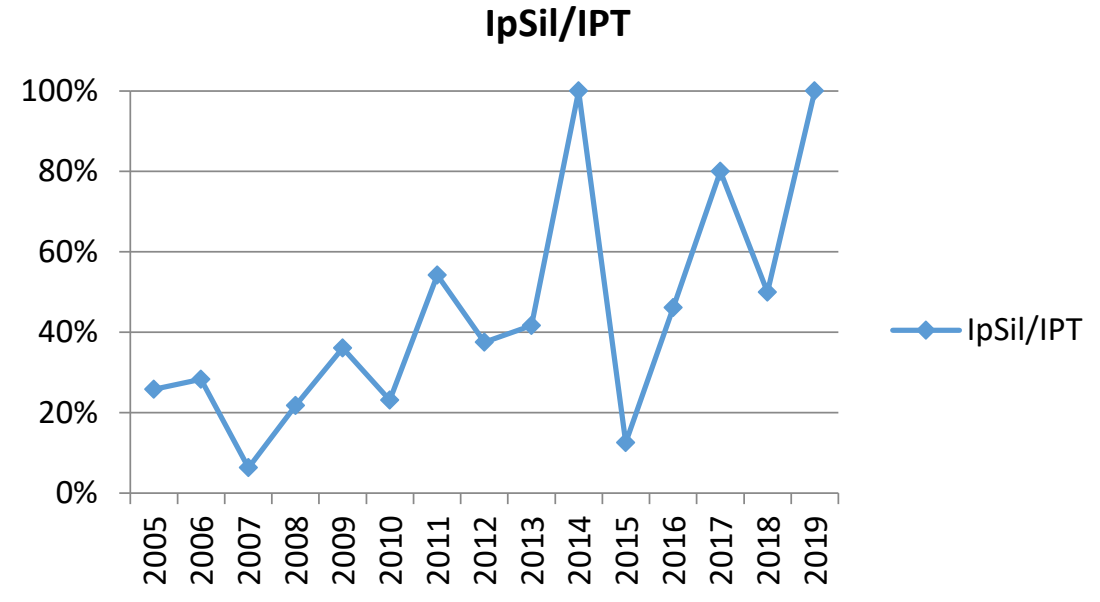

Fig. 1. Variation of the ratio of occupational diseases due to silicosis / total occupational diseases in the period 2005-2019 in Brașov County

\section{Conclusions}

It can say with certainty that most cases of occupational disease are directly and indirectly related to the lack of training of workers or inadequate or insufficient training.

As specified in the legal requirements, OHS training must be provided at the expense of the employer:

- upon employment;

- when changing jobs or transferring;

- when introducing new work equipment or modifications to existing equipment

- when introducing any new technology or working procedure;

- when executing special works.

In order to be as effective as possible and to be adapted to today's technological requirements and taking into account the current epidemiological context, all these trainings should be directed towards the use of the online environment. Currently, the online environment offers us a wide range of e-learning platforms and, last but not least, also solutions for validating trainings by remote electronic signing as it tries to bring this solution and the ssm.ro platform to light.

\section{References}

1. Rose C., Heinzerling A., Patel K., Sack C., Wolff J., et al. (2019): Severe Silicosis in Engineered Stone Fabrication Workers - California, Colorado, Texas, and Washington, 2017-2019. Morbidity and Mortality Weekly Report, ISSN 1545-861, Vol. 68, No 38, p. 813-818, DOI: 10.15585/mmwr.mm6838a1, Available at https://www.cdc.gov/mmwr/volumes/68/wr/pdfs/mm6838a1-H.pdf

2. Hoy R.F., Baird T., Hammerschlag G., Hart D., Johnson A.R. et al. (2018): Artificial stone-associated silicosis: a rapidly emerging occupational lung disease. Occupational \& Environmental Medicine, ISSN 1351-0711, Vol. 75, p. 3-5, DOI: 10.1136/oemed-2017-104428

3. Leung C.C., Yu I.T.-S., Chen W. (2012): Silicosis. The Lancet, ISSN 0140-6736, Vol. 379, No. 9830, p. 2008-2018, DOI:https://doi.org/10.1016/S0140-6736(12)60235-9

4. Thomas C.R., Kelley T.R. (2010): A Brief Review of Silicosis in the United States. Environmental Health Insights, ISSN 1178-6302, Vol. 4, p. 21-26, DOI: 10.4137/EHI.S4628

5. Santos C., Norte A., Fradinho F., Catarino A., Ferreira A.J., Laureiro M., Baganha M.F. (2010): Silicosis - brief review and experience of a pulmonology ward. Revista Portuguesa de Pneumologia, ISSN 2173-5115, Vol. XVI, No. 1, p. 99-115. Available at http://www.scielo.mec.pt/pdf/pne/v16n1/v16n1a06.pdf 
6. Abad A., Gerassis S., Saavedra A., Giraldez E., Garcia J.F., Taboada J. (2019): A Bayesian assessment of occupational health surveillance in workers exposed to silica in the energy and construction industry. Environmental Science and Pollution Research Int., ISSN 0944-1344, Vol. 26, p. 29560-29569, https://doi.org/10.1007/s11356-018$2962-6$

7. Linch K.D. (2002): Respirable Concrete Dust-Silicosis Hazard in the Construction Industry. Applied Occupational and Environmental Hygiene, ISSN 1047-322X, Vol. 17, No 3, p. 209-221, DOI: 10.1080/104732202753438298

8. McDonald A.D., McDonald J.C., Rando R.J., Hughes J.M., Weill H. (2001): Cohort Mortality Study of North American Industrial Sand Workers. I. Mortality from Lung Cancer, Silicosis and Other Causes. The Annals of Occupational Hygiene, ISSN 0003-4878, Vol. 45, No. 3, p. 193-199, https://europepmc.org/article/med/11295143, DOI:10.1093/annhyg/45.3.201

9. Rando R.J., Vacek P.M., Glenn R.E., Kwon C.-W., Parker J.E. (2018): Retrospective Assessment of Respirable Quartz Exposure for a Silicosis Study of the Industrial Sand Industry. Annals of Work Exposures and Health, ISSM 23987316, Vol. 62, No. 8, p. 1021-1032, https://doi.org/10.1093/annweh/wxy064

10. Vacek P.M., Glenn R.E., Rando R.J., Parker J.E., Kanne J.P., Henry D.A., Meyer C.A. (2019): Exposure-response relationships for silicosis and its progression in industrial sand workers. Scandinavian Journal of Work, Environment \& Health, ISSN 1795-990X, Vol 45, No. 3, p. 280-288, doi:10.5271/sjweh.3786

11. Rushton L. (2007) Chronic Obstructive Pulmonary Disease and Occupational Exposure to Silica. Reviews on Environmental Health, ISSN 2191-0308, Vol. 22, No. 4, p. 255-272, DOI: https://doi.org/10.1515/ REVEH.2007.22.4.255, https://www.degruyter.com/view/journals/reveh/22/4/article-p255.xml

12. Paun A. (2018): Mandatory medical examination before employment in Romania. Available at https://accace.com/mandatory-medical-examination-employment-romania/. Accessed: 2020-08-02

13. Kim Y., Park J., Park M. (2016): Creating a Culture of Prevention in Occupational Safety and Health Practice. Safety and Health at Work, ISSN 2093-7911, Vol. 7, No. 2, p. 89-96, DOI: 10.1016/j.shaw.2016.02.002, https://www.researchgate.net/publication/295897238 Creating a Culture of Prevention in Occupational Safety and Health Practice. Accessed: 2020-08-05

14. Mason J. (2009): Ethics in the construction industry: the prospects for a single professional code. International Journal of Law in the Built Environment, ISSN 1756-1450, Vol. 1, No. 3, p. 194-204, DOI: https://doi.org/10.1108/17561450911001252. Accessed: 2020-08-05

15. Batalden B.B., Stoltz P.K. (1993): Framework for the Continual Improvement of Health Care: Building and Applying Professional and Improvement Knowledge to Test Changes in Daily Work. The Joint Commission Journal on Quality Improvement, ISSN 1553-7250, Vol. 19, No. 10, p. 424-447, https://doi.org/10.1002/chp.4750150304

16. Mureșan P.I., Miloșan I., Senchetru D., Reit A.N., Machedon-Pisu T., Oancea G. (2019): Study of health and safety in the manufacturing industry using Pareto analysis. MATEC Web of Conferences 299, 05008, Proceedings of MTeM 2019 Conference, ISBN 978-2-7598-9083-5, p. 1-8, Technical University of Cluj-Napoca, Romania, Available at https://doi.org/10.1051/matecconf/201929905008

17. Targoutzidis A., Koukoulaki E., Schmitz-Felten K., Kuhl M., Karen O., Hengel E., Rijken K., Van den Broek R., Klüser R. (2014): The business case for safety and health at work: Cost-benefit analyses of interventions in small and medium-sized enterprises. European Agency for Safety and Health at Work, ISBN 978-92-9240-495-6, doi: 10.2802/32988, Available at https://osha.europa.eu/en/tools-and-publications/publications/reports/thebusiness-case-for-safety-andhealth-cost-benefit-analyses-of-interventions-in-small-and-medium-sizedenterprises. Accessed: 2020-04-05

18. *** Inspectoratul Teritorial de Muncă Brașov-Raport de activitate pe anul 2019 (Brasov Territorial Labour Inspectorate-2019 Activity Report). Available at http://www.itmbrasov.ro/informatii\%20publice.htm (in Romanian) 